\title{
THE
}

2010

\section{Impacts of Climate Change on Narragansett Bay}

Leslie Smith

University of Rhode Island, leslie.smith@gso.uri.edu

Sandra Whitehouse

Candace A. Oviatt

University of Rhode Island, coviatt@uri.edu

Follow this and additional works at: https://digitalcommons.uri.edu/gsofacpubs

Terms of Use

All rights reserved under copyright.

\section{Citation/Publisher Attribution}

Smith, L. M., Whitehouse, S., \& Oviatt, C. A. (2010). Impacts of Climate Change on Narragansett Bay.

Northeastern Naturalist, 17(1), 77-90. doi: 10.1656/045.017.0106

Available at: https://doi.org/10.1656/045.017.0106

This Article is brought to you for free and open access by the Graduate School of Oceanography at DigitalCommons@URI. It has been accepted for inclusion in Graduate School of Oceanography Faculty Publications by an authorized administrator of DigitalCommons@URI. For more information, please contact digitalcommons-group@uri.edu. 


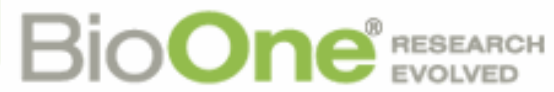

\section{Impacts of Climate Change on Narragansett Bay}

Author(s): Leslie M. Smith, Sandra Whitehouse and Candace A. Oviatt

Source: Northeastern Naturalist, 17(1):77-90.

Published By: Eagle Hill Institute

https://doi.org/10.1656/045.017.0106

URL: http://www.bioone.org/doi/full/10.1656/045.017.0106

BioOne (www.bioone.org) is a nonprofit, online aggregation of core research in the biological, ecological, and environmental sciences. BioOne provides a sustainable online platform for over 170 journals and books published by nonprofit societies, associations, museums, institutions, and presses.

Your use of this PDF, the BioOne Web site, and all posted and associated content indicates your acceptance of BioOne's Terms of Use, available at www.bioone.org/page/terms of use.

Usage of BioOne content is strictly limited to personal, educational, and noncommercial use. Commercial inquiries or rights and permissions requests should be directed to the individual publisher as copyright holder. 


\title{
Impacts of Climate Change on Narragansett Bay
}

\author{
Leslie M. Smith ${ }^{1, *}$, Sandra Whitehouse ${ }^{2}$, and Candace A. Oviatt ${ }^{1}$
}

\begin{abstract}
The objective of this paper is to examine the impacts of global climate change on Rhode Island's coastal ecosystems. Average annual air temperature in Rhode Island has increased by $1.7{ }^{\circ} \mathrm{C}$ since 1880 , water temperatures of Narragansett Bay have increased by $1.2^{\circ} \mathrm{C}$ since 1950 , precipitation increased $27 \%$ between 1895 and 1999, and sea level rose $0.13 \mathrm{~m}$ between 1931 and 2007. We can already see the effects of these climatic changes on the Narragansett Bay ecosystem, including ecological changes in the Bay's food web from phytoplankton and zooplankton to fish, e.g., changes in phenology of seasonal phytoplankton blooms and dominant fish species (e.g., Pseudopleuronectes americanus [Winter Flounder]). These climatic changes have increased freshwater inputs and the concomitant pollutant loads into the Bay. Rising sea level has contributed to ongoing erosion of the coast and has put waterfront homes at increased risk. It is imperative to continue monitoring these effects.
\end{abstract}

\section{Introduction}

Compelling scientific evidence has shown that humans have been a key driving factor in the dramatic changes we have seen in the earth's climate over the last 100 years. The fourth assessment report of the Intergovernmental Panel on Climate Change (IPCC) has determined that it is very likely (90\% certainty) that anthropogenic emissions have contributed to global climate change (IPCC 2007). The climate is changing faster than many ecosystems can adapt, and the rate of change, rather than its magnitude, is the key driver of the stress being placed on these ecosystems. Most forecasts predict that the rate of change will increase over the coming decades.

Global air temperature has increased by $0.74 \pm 0.18^{\circ} \mathrm{C}$ over the last century (IPCC 2007), while surface ocean temperatures (top $300 \mathrm{~m}$ ) has increased $0.17^{\circ} \mathrm{C}$ from 1955 to 2003 (Levitus et al. 2005). A disproportionate amount of this surface ocean temperature change is centered on the North Atlantic Ocean, which has increased at twice the rate as the global average over the same time period (Levitus et al. 2005). Sea-level rise has accelerated in recent years from the average rate of $1.8 \mathrm{~mm}$ per year from 1961-2003 to $3.1 \mathrm{~mm}$ per year in 1993 to 2003 (IPCC 2007). The majority of the sea-level rise can be attributed to thermal expansion (Meehl et al. 2007). An additional effect of the increase in atmospheric concentration of $\mathrm{CO}_{2}$ is an increase in concentration of dissolved $\mathrm{CO}_{2}$ in the oceans, which has lead to a decrease in $\mathrm{pH}$ from 8.25 to 8.14 over the 53 years from 1951 to 2004 (Jacobson 2005). The reduction of $\mathrm{pH}$ in the oceans increases the dissolution rate of calcium carbonate (Caldeira

${ }^{1}$ Graduate School of Oceanography, University of Rhode Island, Box 9, 11 Aquarium Road, Narragansett, RI 02882. ${ }^{2} 32$ Elmgrove Avenue, Providence, RI 02906. "Corresponding author - leslie.smith@gso.uri.edu. 
and Wickett 2003, Feely et al. 2004, Orr et al. 2005) and raises the calcium carbonate horizon, the level in the water column below which calcium carbonate will dissolve (Doney 2006). These two factors threaten sensitive organisms that use calcium carbonate in the production of their shells, e.g., pteropods, foraminifera, corals, and some phytoplankton (Caldeira and Wickett 2003, Feely et al. 2004, Orr et al. 2005)

Global climate change (GCC) is a worldwide phenomenon with consequences not dispersed uniformly across the globe; consequently, different areas will see different effects. Below we detail the patterns of global climate change on Rhode Island's coastal ecosystems, specifically Narragansett Bay, with respect to changes in temperature, precipitation, storm intensity, sealevel rise, and $\mathrm{pH}$.

\section{Rhode Island Impacts}

\section{Temperature increase}

Air temperature in Rhode Island has increased over the past century to varying degrees depending on location and the types of instruments employed. When data in the Historic Climate Network (HCN) are averaged, they indicate that air temperature in Rhode Island increased $1.2{ }^{\circ} \mathrm{C}$ from 1895 to 1999 (New England Regional Assessment Group 2001). The same raw data is utilized by the NASA Goddard Institute for Space Studies (GISS), where it is adjusted for urbanization effects. The average of six long-term GISS data sets from in and around Rhode Island indicate an air temperature increase of $1.7^{\circ} \mathrm{C}$ from 1881 to 2006 (Fig. 1). Data from the Providence and T.F. Green Airport Weather Bureau sites shows an increase in air temperature

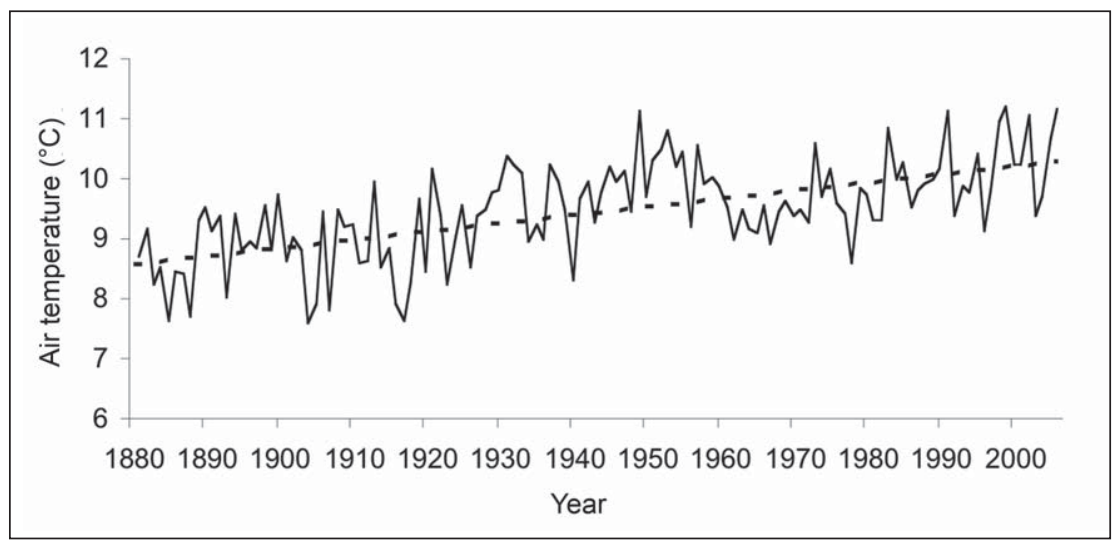

Figure 1. Air temperature in the Rhode Island region from 1881 to 2007. Data is collected from six locations by the NASA Goddard Institute for Space Studies (GISS) averaged by year. Locations and their time ranges include: Providence, RI (41.7N, 71.4W) 1881-2007; Worchester, MA (42.3N, 71.9W) 1949-2004; Kingston, RI (41.5N, 71.5W) 1889-2007; Taunton, MA (41.9N, 71.1W) 1881-2007; Quonset Point, RI (41.6N, 71.4W) 1945-1973; and Block Island, RI (441.2N, 71.6W) 18811995. Data was accessed at http://data.giss.nasa.gov. 
from 1905 to 2006 of $0.9{ }^{\circ} \mathrm{C}$ (Pilson 2008). Global temperatures during this same time period (1905 to 2006) have increased $0.74 \pm 0.18{ }^{\circ} \mathrm{C}$ (IPCC 2007). New England regional temperatures have increased $0.4{ }^{\circ} \mathrm{C}$ between 1895 and 1999 (New England Regional Assessment Group 2001). In all of these records, the cooling of air temperatures during the period of the 1950s through 1970s is evident and consistent with the global trend (IPCC 2007, New England Regional Assessment Group 2001). It appears that air temperature in Rhode Island is increasing at a rate faster than the global or New England regional averages, possibly the result of population growth and urban expansion and/or the influence of the nearby warmer sea-surface temperatures (New England Regional Assessment Group 2001).

Water temperature records show a similar trend to air temperature over the past century. Long-term temperature datasets for water temperature in Narragansett Bay come from observations collected by the National Oceanic and Atmospheric Administration (NOAA) at the Newport Harbor tide gauge (\#8452660) from 1956 to 1999 (Hawk 1998, Nixon et al. 2004) and the University of Rhode Island Graduate School of Oceanography's (GSO) fish trawl surveys collected at Fox Island in the lower West Passage of Narragansett Bay since 1959 (Fig. 2; Collie et al. 2008). These datasets correspond well with the 122-year temperature record from Woods Hole, MA, about $60 \mathrm{~km}$ to the east (Hawk 1998, Nixon et al. 2004) that shows annual temperatures in the 1990s were $1.2{ }^{\circ} \mathrm{C}$ warmer than average annual temperatures from 1890 to 1970 (Nixon et al. 2004). It should be noted that water-temperature trends exhibited the same cooling trends seen in air temperature from 1950-1970 (Nixon et al. 2004). Narragansett Bay water temperature has increased faster than the surface (top $300 \mathrm{~m}$ ) North Atlantic average, which warmed by $0.35^{\circ} \mathrm{C}$ over the

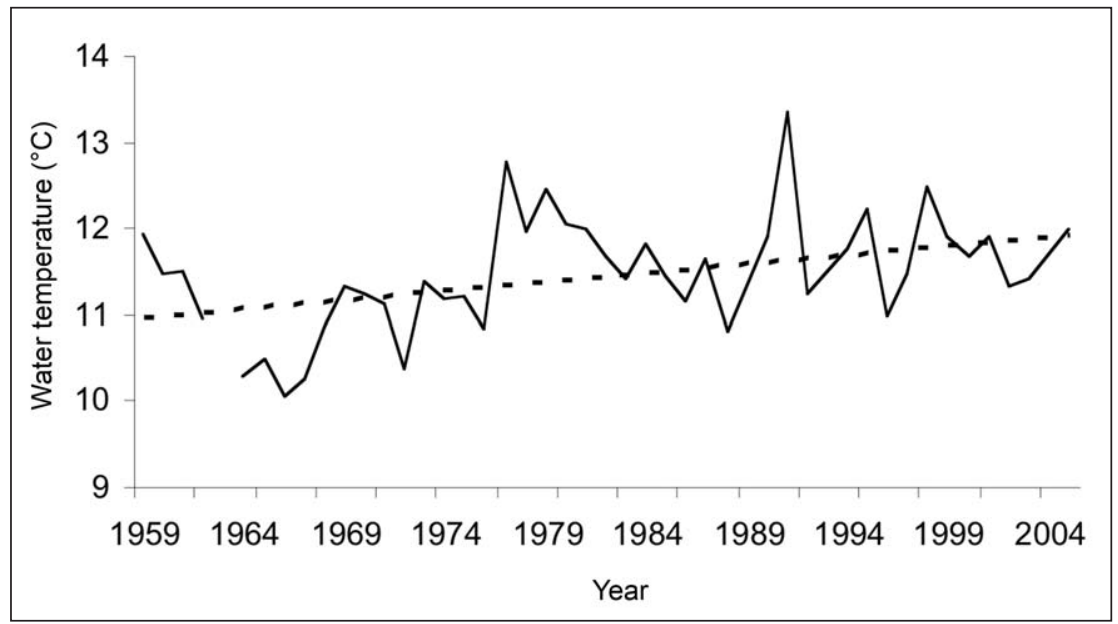

Figure 2. Annual averages of weekly water-temperature measurements at Fox Island in Narragansett Bay, Located in the lower West Passage of Narragansett Bay, show an increase of $0.91{ }^{\circ} \mathrm{C}$ from $1959-2003\left(0.021{ }^{\circ} \mathrm{C} / \mathrm{y}\right)$. (Data was collected as part of weekly GSO fish trawl survey). 
past century (Levitus et al. 2005). This pattern fits the trend found along the east coast in which areas farther north experience a greater increase in water temperature than stations farther south (Maul et al. 2001).

Narragansett Bay is located geographically just below Cape Cod, the demarcation between northern boreal and southern warmer species (Nixon et al. 2009). As a result, though it is considered a temperate estuary, it houses many northern and southern species both on the edges of their zones (Collie et al. 2008). Many marine organisms already live close to their thermal tolerances (Somero 2002); as such, even a slight increase in water temperature could negatively affect their survival (Harley et al. 2006). There have been many effects of increased water temperature at the organism level in Narragansett Bay over the past 100 years.

\section{Changes in the winter-spring bloom cycle}

In Narragansett Bay, phytoplankton is the major primary producer (Pratt 1959 , Smayda 1957). From the 1970 s to 1990 s, there was a $50 \%$ reduction in annual chlorophyll biomass, a proxy for phytoplankton, in the Bay ( $\mathrm{Li}$ and Smayda 1998). This decline has continued through 2006 to an almost $70 \%$ decrease in chlorophyll biomass since the early 1970s (Fulweiler and Nixon 2009). Additionally, phytoplankton phenology has shifted as there has been a decrease in winter-spring bloom biomass (Oviatt 2004), and in some instances there has been an absence of the bloom all together (Oviatt et al. 2002). Several factors moderate phytoplankton growth in the Bay, including bottom-up control by factors such as nutrients and top-down control by grazers such as zooplankton (Keller et al. 1999).

Over the last 120 years, Narragansett Bay has changed dramatically as a result of the industrial revolution and the urbanization of Rhode Island (Hamburg et al. 2008, Nixon et al. 2008). Nutrient input has increased in the Bay during this time and has also become concentrated in the upper bay region closer to the city of Providence (Hamburg et al. 2008, Nixon et al. 2008). The exact amount of the increase over the past few decades is unclear, as different models yield different results depending on input parameters and assumptions made in the model. Nitrogen input into Narragansett Bay has been calculated to have increased between 14\% (Nixon et al. 2008) and $39 \%$ (Hamburg et al. 2008). Water-column production has been found to be positively related to in situ nutrient concentrations through both mesocosm experimentation (Oviatt et al. 1986) as well as field surveys (Oviatt 2008).

In terms of top-down control, an increase in grazing pressure could lead to a decrease in the winter-spring phytoplankton bloom. It has been hypothesized that grazing pressure from zooplankton has increased during the winter-spring period due to warmer winter water temperatures (Edwards and Richardson 2004, Oviatt 2004). The winter-spring phytoplankton bloom cycle itself is independent of temperature changes (Hitchcock and Smayda 1977, Pratt 1965) and is instead dependent on light levels (Hitchcock and Smayda 1977) and grazing pressure (Pratt 1965). So as the temperature changes in the Bay, the winter-spring phytoplankton bloom cycles will not 
shift in concert. Thus, whereas diatom phytoplankton once bloomed in advance of peak zooplankton activity, they now experience increased grazing pressure early in their spring bloom cycle (Edwards and Richardson 2004), effectively suppressing the bloom (Oviatt 2004). Patterns of this nature can be seen in phytoplankton interannual variation from 1977 to 2000 reflecting cold versus warm years (Oviatt 2004). These findings are reinforced through mesocosm experimentation in which a $1{ }^{\circ} \mathrm{C}$ increase in water temperature was shown to lead to a reduction in the winter-spring phytoplankton bloom (Keller et al. 1999). Historically, the winter-spring bloom was a large contributor to total annual chlorophyll-a production (Oviatt 2004), and thus, climate change may be a large factor in the observed decrease in annual average chlorophyll- $a$ levels (Fulweiler and Nixon 2009, Li and Smayda 1998).

The suppression of the winter-spring phytoplankton bloom may be stressing the benthos (Ellis 2002). In the past, phytoplankton from the winter-spring bloom that were not grazed sank to the bottom and served as a key resource for the detritivores that dominate the benthos (Keller et al. 1999, Oviatt 2004, Rudnick and Oviatt 1986), but with the elimination/weakening of the spring bloom, less nutritious zooplankton fecal pellets sink to the benthos instead of nutrient-rich phytoplankton. In the mesocosm experiment referenced above, warmer water led to a halving of the phytoplankton biomass that was produced during the spring bloom period and sank to the benthos (Keller et al. 1999). This change in the downward transport of food has led to alterations in the benthic community, e.g., decrease in polychaete marine worms (Ellis 2002).

There are other potential mechanisms that could cause the observed changes in the phytoplankton spring bloom, e.g., weather oscillations and changes in fish populations. In 1998, the observed shift in the spring bloom was caused by the warmer El Niño winter (Oviatt et al. 2002). Another potential mechanism could be shifts in ctenophore populations (Sullivan et al. 2001), as ctenophores are voracious predators of zooplankton (Deason and Smayda 1982). Changes in the composition of fish communities in Narragansett Bay are significantly correlated with the decrease in chlorophyll- $a$ concentration over the past 50 years (Collie et al. 2008). Specifically, demersal fish abundance is positively correlated and pelagic fish abundance negatively correlated to chlorophyll- $a$ concentration (Collie et al. 2008). More research will be needed to sort out the relative importance of and synergies among these different mechanisms which may impact the spring phytoplankton bloom.

\section{Changes in fish populations}

Historically, overfishing was an important factor in the decline of many fish populations, yet the increase in bay temperatures is becoming a large contributing factor in creating conditions unfavorable for many fish species (Collie et al. 2008, Oviatt et al. 2003). For example, there has been a decrease in cold-water demersal species and an increase in warm-water pelagic fish species (Collie et al. 2008, Oviatt et al. 2003). This shift towards warm-water species is exhibited in mean weighted temperature preference 
of fish and invertebrates in the Bay by $2{ }^{\circ} \mathrm{C}$ from 1959 to 2005 (Collie et al. 2008). Specific decreases have been seen in three demersal fish species: Pseudopleuronectes americanus (Walbaum) (Winter Flounder), Merluccius bilinearis (Mitchell) (Silver Hake), and Urophycis chuss (Waldbaum) (Red Hake) (Collie et al. 2008). Increases have been seen in two species of warmwater pelagic fish (Peprilus triacanthus (Peck) [Butterfish] and Stenotomus chrysops (L.) [Scup]); four species of invertebrates (Homarus americanus Milne Edwards [American Lobster], Cancer irroratus Say [Atlantic Rock Crab], Cancer borealis Stimpson [Jonah Crab], and Loligo pealeii Lesueur [Longfin Inshore Squid]); as well as one elasmobranch (Leucoraja erinacea (Mitchell) [Little Skate]) (Collie et al. 2008).

Cold-water fish species are unable to effectively reproduce in warmer water (Jefferies 1994, Jefferies and Johnson 1974), and so Winter Flounder numbers have decreased 90\% since 1980 in the Bay (Oviatt 2004). Hypotheses regarding the mechanisms for this decline in the Winter Flounder population include an increase in larval predation and sub-optimal conditions for spawning due to increased winter water temperatures over the past 35 years (Collie et al. 2008, Jefferies 1994, Jefferies and Johnson 1974, Oviatt et al. 2003). Peak spawning of Winter Flounder occurs when temperatures are between 2 and $5{ }^{\circ} \mathrm{C}$ and predators are normally either absent or inactive (Jefferies 1994, Jefferies and Terceiro 1985, Pereira et al. 1999). Egg survival, percent hatch, time to hatch, and initial size of Winter Flounder larvae are correlated with cooler springs (Keller and Klein-MacPhee 2000). With increasing winter water temperatures, the predacious shrimp Crangon septemspinosa Say (Grey Sand Shrimp) has remained active through more of the winter and thus has been able to prey on Winter Flounder larvae at times when historically the shrimp would be dormant (Jefferies 1994, 2001; Taylor and Collie 2003; Whitehouse 1994). If the temperature increases predicted for the Bay in the near future result in the water never going below $5{ }^{\circ} \mathrm{C}$, Winter Flounder may not lay their eggs in the Bay or the increasingly active predators may consume all of the eggs. In addition to low reproductive success, fewer Winter Flounder are re-entering the Bay, possibly due to offshore exploitation (Jefferies 2001), further reducing populations in the Bay.

At the same time as a decrease in demersal fish species has been observed, populations of invertebrates have been increasing. For the two-decade period starting in the late 1970s, decapods such as Cancer crabs and American Lobster populations in the Bay have been increasing (Collie et al. 2008, Oviatt 2004). Biomass, as measured from trawl surveys, indicate that the $57 \%$ biomass reduction in fish biomass from the early 1980s to the late 1990s is roughly equivalent to the increase in decapod biomass during that same time period (Oviatt 2004). This shift may reflect a decline in predation of decapods by smaller demersal fish populations (Collie et al. 2008, Oviatt 2004). This shift has also resulted in increased taxonomic diversity in the Bay as fish have been replaced by invertebrates of multiple phyla (Collie et al. 2008). 
The fish community of Narragansett Bay over the past 47 years is characterized by an increasing number of fish of a decreasing mean size (Collie et al. 2008), a pattern consistent with overfishing and climate change (Collie et al. 2008). These two forces acting in concert have the potential to reduce fish population sizes to levels below which they can not recover (Scavia et al. 2002). Other factors, such as decreased chlorophyll- $a$ concentration, a shift towards positive Atlantic Multidecal Oscillation (AMO) cycles (Collie et al. 2008), and eutrophication (Deacutis 2008), also play a role in fish species composition shifts in the Bay. These factors will also interact with fishing effort and stock size (Harley et al. 2006).

\section{Change in precipitation}

Though global-scale changes in precipitation are highly variable, a significant trend of increasing precipitation can be seen in eastern North America (IPCC 2007). In the New England region, precipitation has increased 4\% (3.8 cm) from 1895 to 1999 (New England Regional Assessment Group 2001). Just as with the temperature, Rhode Island has seen a larger increase in precipitation-27\% (30 cm) — during the same time period (New England Regional Assessment Group 2001, Pilson 2008).

In addition to increasing total precipitation, there has been an $88 \%$ increase in the frequency of extreme precipitation events in Rhode Island since 1948, the largest increase of any state in the United States (Madsen and Figdor 2007). Extreme precipitation events are defined as all events with the 24-hour precipitation total greater than the smallest of the maximum annual precipitation events for each year of the 59-year study (Madsen and Figdor 2007). The limited available data means that the confidence interval associated with this increase is quite large (24\% to $152 \%)$. The $10 \%$ increase in freshwater input to the Bay since 1960 (Pilson 2008) is likely the result of the changing precipitation patterns and could have far reaching consequences for the Bay, e.g., decreasing salinity, and increasing stratification, turbidity, and terrestrial-derived nutrient inputs (Harley et al. 2006). The impacts caused by increased precipitation will be compounded by hydrograph changes caused by urban development and wetland losses (Rogers and McCarty 2000).

Tropical cyclone intensity has increased in the North Atlantic over the past 40 years (Goldenberg et al. 2001, Meehl et al. 2007, Solomon et al. 2007, Trenberth et al. 2007, Webster et al. 2005) as illustrated by the doubling of the number of category 4 and 5 tropical cyclones since the 1970s (Webster et al. 2005). The strength of tropical cyclones is predicted to continue to increase in the North Atlantic over the next century (Emmanuel 2005, Mann and Emanuel 2006, Scavia et al. 2002). Though globally the number of tropical cyclones is predicted to remain the same or even decrease, the number of hurricanes in the North Atlantic has been and will continue to increase (Oouchi et al. 2006, Webster et al. 2005). Increased tropical cyclone intensity could have large effects on Rhode Island beaches, with greater storm surges overwashing more barrier beaches, redistributing their sediment, and 
more frequently breaching the barrier beaches (Morton and Sallenger 2003). This increase in barrier breaches could have large effects on coastal lagoonal ecosystems in southern Rhode Island, increasing the flushing rate and salinity of the lagoons (Bird 1994, Smith 1994).

Damage from a major hurricane if it were to strike in the future would be particularly devastating for Rhode Island given its increasingly coastal demographics; there has been an approximate doubling in population and wealth of the population in coastal counties from 1938 to 1995 (Pielke and Landsea 1998). The last category-3 hurricane to directly impact the Bay, the hurricane of 1938, caused $\$ 3.6$ billion (1995 dollars) in damage in New York, Connecticut, Rhode Island, and Massachusetts combined (Pielke and Landsea 1998). If that same hurricane were to have hit the region in 1995, the damage would have been approximately $\$ 16.6$ billion (1995 dollars; Pielke and Landsea 1998).

\section{Sea-level rise}

Sea level has increased by $13 \mathrm{~cm}$ from 1931 to 2007 in Narragansett Bay, as recorded in long-term data from NOAA tide gauge stations in Providence (\#845400) and Newport (\#8452660) (Fig. 3). With so much of the population living along the coast, this sea-level rise will have potentially large negative economic and ecologic impacts. The observed rate of increase of $0.17 \mathrm{~m} /$ century is the same as the observed average global rate (IPCC 2007). Increasing global rates of warming will accelerate rates of sea-level rise globally and locally (Meehl et al. 2007, Overpeck et al. 2006).

In the Narragansett Bay region, isostatic shifting has lead to land subsidence of $0.15 \mathrm{~m} /$ century (Boothroyd et al. 1998), thus the total elevational shift along the coast of Rhode Island over the past century is about

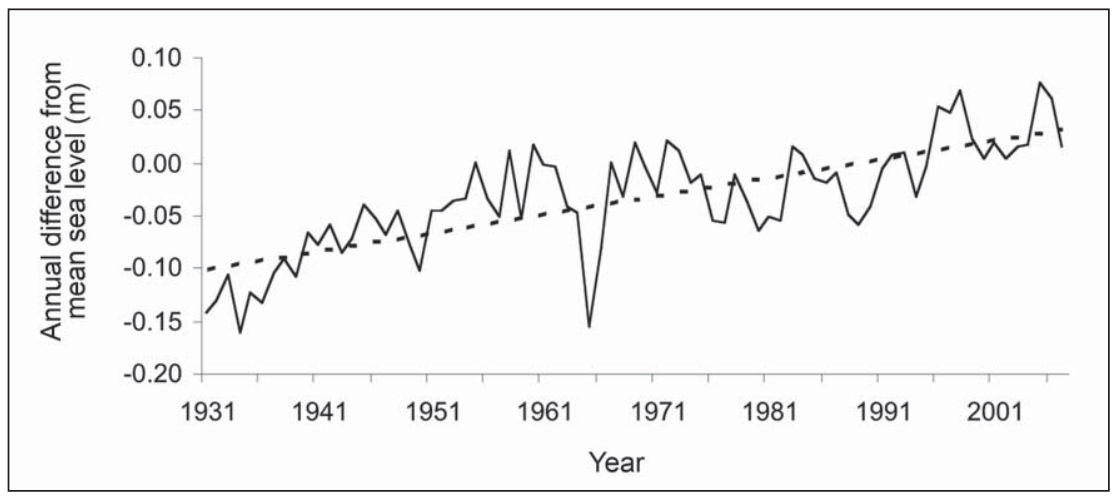

Figure 3. Annual average sea level in Narragansett Bay as derived from NOAA tide gauges in Newport (\#8452660) and Providence (\#845400), RI. The data represent the difference from mean sea level. Mean sea level is defined and determined by NOAA as the arithmetic mean of hourly tidal heights observed from 1983-2001. Thus, a negative number would indicate that the annual mean was lower than mean sea level for that location, and a positive number would indicate the annual mean was higher than mean sea level. Data was accessed at: http://tidesandcurrents.noaa.gov. 
$0.29 \mathrm{~m} /$ century. This combined shift means that upland lands near lowland tidal areas are being flooded, beach erosion has increased, and barrier islands are migrating at increasing rates (Scavia et al. 2002). Additionally, rising water tables resulting from these factors will cause increased failures in septic and storm drainage systems in more than half of the state's coastal areas (Bertness and Ewanchuk 2002, Sea Grant 2004). If the combined rate of sealevel rise and land subsidence exceeds the accretion rate of the salt marsh, salt marshes will be inundated, leading to the destruction of large areas of these critical ecosystems (Donnelly and Bertness 2001). Presently, the accretion rate of low- and high-marsh habitats, $0.43 \mathrm{~cm}$ per year and $0.24 \mathrm{~cm}$ per year, respectively (Bricker-Urso et al. 1989), still exceeds the combined rate of subsidence and sea-level rise in Rhode Island, yet that is not predicted to be the case in the future (Meehl et al. 2007).

The sediments of Rhode Island's barriers and headlands are glacially derived and as such are highly susceptible to increased erosion resulting from sea-level rise, with the south shore of Rhode Island being particularly vulnerable (Boothroyd 1999). Currently, the south shore is retreating on average 30-70 cm per year (Sea Grant 2004), reflecting the joint effects of sea-level rise (long-term factor) and sporadic extreme events (short-term factors). Increases in sea level have an additive effect when coupled with storm surge, causing waves to break higher on bluffs and dunes during coastal storms (Boothroyd et al. 1998). Even an increased storm surge of 25-50 cm can greatly increase erosion rates (Boothroyd 1999).

\section{Bay acidification}

Several factors influence the variability of $\mathrm{pH}$ in seawater, such as changes in the concentration of total dissolved $\mathrm{CO}_{2}$, alkalinity, and temperature (Hinga 2002). The magnitudes of these variations in $\mathrm{pH}$ are linked to the salinity of the seawater, as the concentration of salt influences the $\mathrm{pH}$-buffering properties of the seawater (Hinga 2002). As a result, the $\mathrm{pH}$ of Narragansett Bay is more variable than the $\mathrm{pH}$ of the open ocean, showing a fluctuation of $>0.5$ units above or below the equilibrium depending on seasonal productivity cycles (Hinga 2002) and variation in freshwater input (Mitchell and Rakestraw 1933, Mitchell and Solinger 1934). As a result, the effects of an overall decrease in $\mathrm{pH}$ resulting from increased atmospheric concentrations of carbon dioxide may be different in Narragansett Bay than in the open ocean. Compounding the influence of increasing carbon dioxide are the effects of chronic eutrophication of Narragansett Bay (Hinga 2002). Further research is needed to untangle the net effects of decreasing in $\mathrm{pH}$ in Narragansett Bay.

\section{Conclusions}

Narragansett Bay and coastal Rhode Island have been negatively affected by climate change, and these effects are likely to worsen as warming and $\mathrm{CO}_{2}$ concentrations increase. With the long residence time of $\mathrm{CO}_{2}$ in the atmosphere 
(100 years on average) and the even longer residence time in the ocean (1000 to 1500 years), any emissions reductions we make now will not positively influence the environment for many years. It is essential not only to look at global averages of climate change but also at changes in specific regions, as they will differ greatly. For instance, ecosystem change in Narragansett Bay can impact fish populations, which in turn can have significant effects on commercial and recreational fishermen. Increased erosion along the coastline can damage property and lead to the loss of valuable beaches. Additionally, there are increased threats of flooding and property damage by hurricanes.

\section{Acknowledgments}

We thank Senator Sheldon Whitehouse for so graciously hosting this literature review. The research was sponsored by NSF IGERT grant \#0504103 to the University of Rhode Island Coastal Institute. We also wish to thank Rele Abiade, Mindy Meyers, and George Carvalho from Senator Whitehouse's office for their mentorship on this project. We also thank Dr. Michael Pilson, Dr. John Merrill, Dr. Steven Hamburg, Don Pryor, Gail Scowcroft, Russell Perry, Dana Smith, Russell Smith, Warren Schudy, the Coastal Institute IGERT Project (CIIP) faculty, and CIIP trainees for their contributions to this paper.

\section{Literature Cited}

Bertness, M.D., and P.J. Ewanchuk. 2002. Latitudinal and climate-driven variation in the strength and nature of biological interactions in New England salt marshes. Oecologia 132:392-401.

Bird, E.C.F. 1994. Physical setting and geomorphology of coastal lagoons. Pp. 9-40, In B. Kjerfve (Ed.). Coastal Lagoon Processes. Elsevier, Amsterdam, The Netherlands. 577 pp.

Boothroyd, J. 1999. Chapter 6: Storm hazards. Pp.135-152, In L.M. Ernst, L.K. Miguel, and J. Willis (Eds.). Rhode Island's Salt Pond Region: A Special Area Management Plan. Coastal Resource Management Council, Providence, RI. 224 pp.

Boothroyd, J.C., J.P. Klinger, and C. Galagan. 1998. Coastal geologic hazards on the south shore of Rhode Island. Pp. A5-1-A5-29, In D.P. Murray (Ed.). Guidebook to Field Trips in Rhode Island and Adjacent Regions of Connecticut and Massachusetts. New England Intercollegiate Geological Conference $90^{\text {th }}$ Meeting. University of Rhode Island, Kingston, RI.

Bricker-Urso, S., S.W. Nixon, J.K. Cochran, D.J. Hirshberg, and C. Hunt. 1989. Accretion rates and sediment accumulation in Rhode Island Salt Marshes. Estuaries 12:300-317.

Caldeira, K., and M.E. Wickett. 2003. Anthropogenic carbon and ocean pH. Nature 425:365.

Collie, J.S., A.D. Wood, and H.P. Jefferies. 2008. Long-term shifts in the species composition of a coastal fish community. Canadian Journal of Fisheries and Aquatic Science 65:1352-1365.

Deacutis, C.F. 2008. Evidence of ecological impacts from excess nutrients in upper Narragansett Bay. Pp. 349-381, In A. Desbonnet and B.A. Costa-Pierce (Eds.). Science for Ecosystem-Based Management: Narragansett Bay in the 21st Century. Springer, New York, NY. 570 pp. 
Deason, E., and T. Smayda. 1982. Ctenophore-zooplankton-phytoplankton interactions in Narragansett Bay, Rhode Island, USA, during 1972-1977. Journal of Plankton Research 4:203-217.

Doney, S.C. 2006. The dangers of ocean acidification. Scientific American 294:58-65.

Donnelly, J.P., and M.D. Bertness. 2001. Rapid shoreward encroachment of salt marsh cordgrass in response to accelerated sea-level rise. Proceedings of the National Academy of Sciences 98:14218-14223.

Edwards, M., and A.J. Richardson. 2004. Impact of climate change on marine pelagic phenology and trophic mismatch. Nature 430:881-884.

Ellis, G. 2002. An examination of the benthic macrofauna of Narragansett Bay and the possible implications of winter-spring bloom intensity on population size. M.Sc. Thesis. University of Rhode Island, Narragansett, RI. $181 \mathrm{pp.}$

Emmanuel, K.A. 2005. Increasing destructiveness of tropical cyclones over the past 30 years. Nature 436:686-688.

Feely, R.A., C.L. Sabine, K. Lee, W. Berelson, J. Kleypas, V.J. Fabry, and F.J. Millero. 2004. Impact of anthropogenic $\mathrm{CO}_{2}$ on the $\mathrm{CaO}_{3}$ system in the oceans. Science 305:362-366.

Fulweiler, R.W., and S.W. Nixon. 2009. Responses of benthic-pelagic coupling to climate change in a temperate estuary. Hydrobiologia 629:147-156.

Goldenberg, S.B., C.W. Landsea, A.M. Mestas-Nunez, and W.M. Gray. 2001. The recent increase in Atlantic hurricane activity: Causes and implications. Science 293:474-479.

Hamburg, S.P., D. Pryor, and M.A. Vadeboncouer. 2008. Nitrogen inputs to Narragansett Bay: An historical perspective. Pp. 177-210, In A. Desbonnet, and B.A. Costa-Pierce (Eds.). Science for Ecosystem-Based Management: Narragansett Bay in the 21 st Century. Springer, New York, NY. 570 pp.

Harley, C.D.G., A.R. Hughes, K.M. Hutgren, B.G. Miner, C.J.B. Sorte, C.S. Thornber, L.F. Rodriguez, L. Tomanek, and S.L. Williams. 2006. The impacts of climate change in coastal marine systems. Ecology Letters 9:228-241.

Hawk, J.D. 1998. The role of the North Atlantic oscillation in winter climate variability as it relates to the winter-spring bloom in Narragansett Bay. M.Sc. Thesis, University of Rhode Island, Narragansett, RI.

Hinga, K.R. 2002. Effects of pH on coastal marine phytoplankton. Marine Ecology Progress Series. 238:281-300.

Hitchcock, G.L., and T.J. Smayda. 1977. Importance of light in initiation of 19721973 winter-spring diatom bloom in Narragansett Bay. Limnology and Oceanography 22:126-131.

Intergovernmental Panel on Climate Change (IPCC). 2007. Summary for policy makers. Pp. 1-17, In S. Solomon, D. Qin, M. Manning, Z. Chen, M. Marquis, K.B. Averyt, M. Tignor, and H.L. Miller (Eds.). Climate Change 2007: The Physical Science Basis. Contribution of Working Group I to the Fourth Assessment Report of the Intergovernmental Panel on Climate Change. Cambridge University Press, Cambridge, UK and New York, NY. 996 pp.

Jacobson, M.Z. 2005. Studying ocean acidification with conservative, stable numerical schemes for nonequilibrium air-ocean exchange and ocean equilibrium chemistry. Journal of Geophysical Research 110:D07302.

Jefferies, H.P. 1994. The impacts of warming climate on fish populations. Maritimes $37: 12-15$.

Jefferies, H.P. 2001. Rhode Island's ever changing Narragansett Bay. Maritimes $43: 3-6$. 
Jefferies, H.P., and W.C. Johnson. 1974. Seasonal distributions of bottom fishes in Narragansett Bay area: seven-year variations in the abundance of winter flounder (Pseudopleuronectes americanus). Journal Fisheries Research Board of Canada 31:1057-1066.

Jefferies, H.P., and M. Terceiro. 1985. Cycle of changing abundances in the fishes of the Narragansett Bay area. Marine Ecological Progress Series 25:239-244.

Keller, A., and G. Klein-MacPhee. 2000. Impact of elevated temperature on the growth, survival, and trophic dynamics of winter flounder larvae: A mesocosm study. Canadian Journal of Fisheries and Aquatic Sciences 57:2382-2392.

Keller, A.A., C.A. Oviatt, H.A. Walker, and J.D. Hawk. 1999. Predicted impacts of elevated temperature on the magnitude of the winter-spring phytoplankton bloom in temperate coastal waters: A mesocosm study. Limnology and Oceanography 44:344-356.

Levitus, S., J. Anthony, and T. Boyer. 2005. Warming of the world ocean 1955-2003. Geophysical Research Letters 32:L02604.

Li, Y., and T.J. Smayda. 1998. Temporal variability of chlorophyll in Narragansett Bay, 1973-1990. International Council for the Exploration of the Sea Journal of Marine Science 55:661-667.

Madsen, T., and E. Figdor. 2007. When it rains, it pours: Global warming and the rising frequency of extreme precipitation in the United States. Environment Rhode Island Research and Policy Center, Providence, RI.

Mann, M.E., and K.A. Emanuel. 2006. Atlantic hurricane trends linked to climate change. American Geophysical Union 87:233-244.

Maul, G.A., A.M. Davis, and J.W. Simmons. 2001. Sea-water temperature trends at USA tide-gauge sites. Geophysical Research Letters 28:3935-3938.

Meehl, G.A., T.F. Stocker, W.D. Collins, P. Friedlingstein, A.T. Gaye, J.M. Gregory, A. Kitoh, R. Knutti, J.M. Murphy, A. Noda, S.C.B. Raper, I.G. Watterson, A.J. Weaver, and Z. Zhao. 2007. Global climate projections. Pp. 747-845, In S. Solomon, D.Qin, M. Manning, Z. Chen, M. Marquis, K.B. Averyt, M. Tignor and H. L. Miller (Eds.). Climate change 2007: The Physical Science Basis. Contribution of Working Group I to the Fourth Assessment Report of the Intergovernmental Panel on Climate Change. Cambridge University Press, Cambridge, UK and New York, NY, 996 pp.

Mitchell, P.H., and N.W. Rakestraw. 1933. The buffer capacity of sea water. Biological Bulletin 65:437-451.

Mitchell, P.H., and J.L. Solinger. 1934. The effects of land drainage upon the excess bases of sea water. Biological Bulletin 66:97-101.

Morton, R.A., and J.A.H. Sallenger, Jr. 2003. Morphological impacts of extreme storms on sandy beaches and barriers. Journal of Coastal Research 19:560-573.

New England Regional Assessment Group. 2001. Preparing for a changing climate: The potential consequences of climate variability and change-New England Regional Overview. US Global Change Research Program, University of New Hampshire, Durham, NH. 96 pp.

Nixon, S.W., S.L. Granger, B.A. Buckley, M. Lamont, and B. Rowell. 2004. A one hundred and seventeen year coastal water temperature record from Woods Hole, Massachusetts. Estuaries 27:397-404.

Nixon, S.W., B.A. Buckley, S.L. Granger, L.A. Harris, A.J. Oczkowski, R.W. Fulweiler, and L.W. Cole. 2008. Nitrogen and phosphorus inputs to Narragansett Bay: Past, present, and future. Pp. 101-175, In A. Desbonnet, and B.A. CostaPierce (Eds.). Science for Ecosystem-Based Management: Narragansett Bay in the 21 st Century. Springer, New York, NY. 570 pp. 
Nixon, S.W., R.W. Fulweiler, B.A. Buckley, S.L. Granger, B.L. Nowicki, and K.M. Henry. 2009. The impact of changing climate on phenology, productivity, and benthic-pelagic coupling in Narragansett Bay. Estuarine, Coastal, and Shelf Science 82:1-18.

Oouchi, K., J. Yoshimura, H. Yoshimura, R. Mizuta, S. Kusunoki, and A. Noda. 2006. Tropical cyclone climatology in a global-warming climate as simulated in a $20-\mathrm{km}$-mesh global 20 atmospheric model: Frequency and wind-intensity analysis. Journal of the Meteorological Society of Japan 84:259-276.

Orr, J.C., V.J. Fabry, O. Aumon, L. Bopp, S.C. Doney, R.A. Feely, A. Gnanadesikan, N. Gruber, A. Ishida, F. Joos, R.M. Key, K. Lindsay, E. Maier-Reimer, R. Matear, P. Monfray, A. Mouchet, R.G. Najjar, G. Plattner, K.B. Rodgers, C.L. Sabine, J.L. Sarmiento, R. Schlitzer, R.D. Slater, I.J. Totterdell, M. Weirig, Y. Yamanaka, and A. Yool. 2005. Anthropogenic ocean acidification over the twenty-first century and its impact on calcifying organisms. Nature 437:681-686.

Overpeck, J.T., B.L. Otto-Biesner, G.H. Miller, D.R. Muhs, R.B. Alley, and J.T. Kiehl. 2006. Paleoclimatic evidence for future ice-sheet instability and rapid sea-level rise. Science 311:1747-1750.

Oviatt, C. 2004. The changing ecology of temperate coastal waters during a warming trend. Estuaries 27:895-904.

Oviatt, C.A. 2008. Impacts of nutrients on Narragansett Bay productivity: A gradient approach. Pp 523-544, In A. Desbonnet, and B. A. Costa-Pierce (Eds.). Science for Ecosystem-Based Management: Narragansett Bay in the 21st Century. Springer, New York, NY. 570 pp.

Oviatt, C.A., A.A. Keller, P.A. Sampou, and L.L. Beatty. 1986. Patterns of productivity during eutrophication: A mesocosm experiment. Marine Ecology Progress Series 28:69-80.

Oviatt, C., A. Keller, and L. Reed. 2002. Annual primary production in Narragansett Bay with no bay-wide winter-spring phytoplankton bloom. Estuarine, Coastal, and Shelf Science. 54:1013-1026.

Oviatt, C., S. Olsen, M. Andrews, J. Collie, T. Lynch, and K. Raposa. 2003. A century of fishing and fish fluctuations in Narragansett Bay. Reviews in Fisheries Science $11: 221-242$.

Pereira, J.J., R. Goldberg, J.J. Ziskowski, P.L. Berrien, W.W. Morse, and D.L. Johnson. 1999. Essential fish habitat source document: Winter Flounder, Pseudopleuronectes americanus, life history and habitat characteristics. NOAA Technical Memorandum NMFS-NE-138. 48pp.

Pielke, R.A., and L.W. Landsea. 1998. Normalized hurricane damages in the United States: 1925-95. American Meteorological Society 13:621-631.

Pilson, M.E.Q. 2008. Narragansett Bay amidst a globally changing climate. Pp. 35-46, In A. Desbonnet, and B. A. Costa-Pierce (Eds.). Science for EcosystemBased Management: Narragansett Bay in the 21st Century. Springer, New York, NY. 570 pp.

Pratt, D.M. 1959. The phytoplankton of Narragansett Bay. Limnology and Oceanography 4:425-440.

Pratt, D.M. 1965. Winter-spring diatom flowering in Narragansett Bay. Limnology and Oceanography 10:173-184.

Rogers, C.E., and J.P. McCarty. 2000. Climate change and ecosystems of the MidAtlantic region. Climate Research 14:235-244.

Rudnick, D.T., and C.A. Oviatt. 1986. Seasonal lags between organic carbon deposition and mineralization in marine sediments. Journal of Marine Research 44:815-837. 
Scavia, D., J.C. Field, D.F. Boesch, R.W. Buddemeier, V. Burkett, and D.R. Cayan. 2002. Climate-change impacts on US coastal and marine ecosystems. Estuaries 25:149-164.

Sea Grant. 2004. Rhode Island Sea Grant fact sheets: Coastal erosion. Rhode Island Sea Grant. Available online at http://seagrant.gso.uri.edu/factsheets/fserosion. html. Accessed 23 April 2007.

Smayda, T.J. 1957. Phytoplankton studies in lower Narragansett Bay. Limnology and Oceanography 2:342-359.

Smith, N.P. 1994. Water, salt, and heat balance of coastal lagoons, Pp. 69-101, In B. Kjerfve (Ed.). Coastal Lagoon Processes. Elsevier, Amsterdam, The Netherlands. $577 \mathrm{pp}$.

Solomon, S., D. Qin, M. Manning, R.B. Alley, T. Bernsten, N.L. Bindoff, Z. Chen, A. Chidthaison, J.M. Gregory, G.C. Hegrel, M. Heimann, B. Hewitson, B.J. Hoskins, F. Joos, J. Jouzel, V. Kattsov, U. Lohmann, T. Matsuno, M. Molina, N. Nicholls, J. Overpeck, G. Raga, V. Ramaswamy, J. Ren, M. Rusticucci, R. Somerville, T.F. Stocker, P. Whetton, R.A. Wood, and D. Wratt. 2007. Technical Summary. Pp. 19-91, In S. Solomon, D. Qin, M. Manning, Z. Chenb, M. Marquis, K. B. Averyt, M. Tignor, and H.L. Miller (Eds.). Climate Change 2007: The Physical Science Basis. Contribution of Working Group I to the Fourth Assessment Report of the Intergovernmental Panel on Climate Change. Cambridge University Press, Cambridge, United Kingdom and New York, NY, USA. 996 pp.

Somero, G. N. 2002. Thermal physiology and vertical zonation of intertidal animals: Optima, limits, and costs of living. Integrative and Comparative Biology 42:780-789.

Sullivan, B.K., D. Vankeuren, and M. Clancy. 2001. Timing and size of blooms of the ctenophore Mnemiopsis leidyi in relation to temperature in Narragansett Bay, Rhode Island. Hydrobiologia 451:113-120.

Taylor, D., and J. Collie. 2003. Effect of temperature on the functional response and foraging behavior of the Sand Shrimp Crangon septemspinosa preying of juvenile Winter Flounder Pseudopleuronectes americanus. Marine Ecology Progress Series 363:217-234.

Trenberth, K.E., P.D. Jones, P. Ambenje, R. Bojariu, D. Easterling, A.K. Tank, D. Parker, F. Rahimzadeh, J. A. Renwick, M. Rusticucci, B. Soden, and P. Zhai. 2007. Observations: Surface and atmospheric climate change. Pp. 235-336, In S. Solomon, D. Qin, M. Manning, Z. Chen, M. Marquis, K.B. Averyt, M. Tignor, and H. L. Miller (Eds.). Climate change 2007: The Physical Science Basis. Contribution of Working Group I to the Fourth Assessment Report of the Intergovernmental Panel on Climate Change. Cambridge University Press, Cambridge, U.K and New York, NY. 996 pp.

Webster, P.J., G.J. Holland, J.A. Curry, and H.R. Chang. 2005. Changes in tropical cyclone number, duration, and intensity in a warming environment. Science 309:1844-1846.

Whitehouse, S.T. 1994. The abundance and distribution of Cragnon septemspinosa in Narragansett Bay. Ph.D. Dissertation. University of Rhode Island, Kingston, RI. 189 pp. 